\title{
Environmental isotope investigation for the identification of source of springs observed in the hillock on the left flank of Gollaleru Earthen Dam, Andhra Pradesh, India
}

\author{
J Noble* ${ }^{*}$ and MD Arzoo Ansari \\ Isotope Hydrology Section, Isotope and Radiation Application Division, Bhabha Atomic Research Centre, \\ Trombay, Mumbai 400 085, India. \\ *Corresponding author.e-mail: noblej@barc.gov.in
}

MS received 8 September 2016; revised 6 January 2017; accepted 16 February 2017; published online 18 July 2017

A hydrometric, hydrochemical and environmental isotopic study was conducted to identify the source and origin of observed springs on the foot of the hillock abutting the left flank of the Gollaleru earthen dam, Nandyal, Andhra Pradesh, India. Water samples (springs, reservoir water and groundwater) in and around the dam area were collected and analyzed for environmental isotopes $\left(\delta^{18} \mathrm{O}, \delta^{2} \mathrm{H}\right.$ and $\left.{ }^{3} \mathrm{H}\right)$ and hydrochemistry. Reservoir level, spring discharges and physico-chemical parameters (temperature, electrical conductivity, $\mathrm{pH}$, etc.) were monitored in-situ. Isotopic results indicated that the source of springs is from the Owk reservoir and groundwater contribution to the springs is insignificant. Based on hydrometric observations, it is inferred that the springs might be originated from the reservoir level of $209 \mathrm{~m}$ amsl. It is found that the lower spring discharges were derived from diffuse sources (seepage) which could be a mixture of reservoir water and the groundwater, while the relatively higher spring discharges were resulted from concentrated sources (leakage) from the reservoir. Thus, the study portraits the usefulness of isotope techniques in understanding the dam seepage/leakage related problems.

Keywords. Stable isotopes; seepage; leakage; reservoir; hydrometry.

\section{Introduction}

Leakage or seepage in dams and reservoirs can cause water losses and likely structural instabilities induced by water leakage pathways, and hence linked to economic repercussions. Leakage can be defined as concentrated water losses derived from structural or construction deficiencies such as those found at contact surface between the dam body and the terrain, lack of or deficient isolation of alluvial materials, activation of perched old karstification when flooded by the reservoir water, etc., while in the case of seepage, groundwater flows through concentrated pathways and emerges downstream, forming springs (Bedmar and Araguas 2002). The leakage or seepage may either occur through the walls and foundation of the dam or through natural geological formations of the dam site. Remedial measures are usually very costly and, in most cases, they are executed without having sufficient knowledge on the nature of problem associated with it. Hence, multi-disciplinary techniques are generally required for the proper analysis of seepage related problems. The most commonly used techniques in the study of seepage or leakage in dams and reservoirs include (a) hydrometric measurements (Lee et al. 2005; Unal et al. 2007), (b) geophysical methods (Panthulu et al. 2001; Cho and Yeom 2007; Sjödahl et al. 2008), (c) measurement of environmental isotopes (Peng and Wang 2008; 
Saravana Kumar et al. 2008; Fan et al. 2014), (d) use of artificial (fluorescent and radioactive) tracers (Iya et al. 1967; Hien and Ki-Ioi 1996; Lee et al. 2007) and (e) numerical modelling (Aral and Maslia 1983; Gurocak and Alemdag 2011). Although, several hydrological studies have been reported in the literature to understand the seepage/leakage related problems of dams and reservoirs, not many studies have been reported on the application of environmental isotope techniques.

Natural tracers of water namely, temperature, electric conductivity, chemical constituents present in water and the stable isotopes of water $\left({ }^{2} \mathrm{H}\right.$ and ${ }^{18} \mathrm{O}$ ) are proved to be useful tracers for the identification of the origin of emerging water at the discharge points located downstream of the dam and localization of infiltration points in lakes and reservoirs (Bedmar and Araguas 2002). Since the stable isotopes, ${ }^{2} \mathrm{H}$ and ${ }^{18} \mathrm{O}$, are part of the water molecule, they can be used as ideal tracers to trace the movement and mixing of water from different sources (Clark and Fritz 1997). Apart from this, environmental tritium, formed in the upper atmosphere and a fall out of thermo nuclear test carried out in the atmosphere during 1950-1963 could be effectively used to identify recent recharge (estimate residence time) to groundwater.

The Srisailam Project, a hydro-electric cum irrigation unit, is a major dam constructed across the River Krishna in Andhra Pradesh (AP), India. The water in the reservoir is diverted for irrigation through a canal located on the right bank of the river and is expected to irrigate about 76,900 hectares of drought prone areas in Nandyal, Banaganapalli and Koilakuntla taluks of Kurnool district and Jammalamadugu taluk of Cuddapah district, A.P. The construction of Srisailam Right Branch Canal (SRBC), with a proposed length of $198 \mathrm{~km}$, started in 1983. The SRBC runs through a hillock at a chainage of $114.5 \mathrm{~km}$ with a tunnel (Owk tunnel) of $1.91 \mathrm{~km}$ long, before entering into the Owk reservoir (figure 1). The Owk reservoir is located at a chainage of $116.6 \mathrm{~km}$ of the SRBC. The water received from the Owk tunnel enters into the Paleru reservoir, passes to Gollaleru valley through a link channel and from Gollaleru to Thimmaraju valley through another link channel and discharges into SRBC at a chainage of $119.7 \mathrm{~km}$ through a regulator at the extreme right flank of Thimmaraju dam. Three earthen dams namely, Paleru $(1.0 \mathrm{~km}$ long), Gollaleru (1.1 km) and Thimmaraju (0.7 $\mathrm{km}$ ) were constructed on the Owk reservoir with the purpose of storing water from the Srisailam
Right Bank Canal (SRBC) for irrigation and flood control.

Just after the construction of the Paleru, Gollaleru and Thimmaraju earthen dams, in March 2003, on trial basis, some amount of Krishna river water was released from the Srisailam dam and the reservoir level was raised to $212.4 \mathrm{~m}$ amsl. Soon after the reservoir level was raised, five lower discharge springs appeared at the foot of the hillock, which is abutting the left flank of the Gollaleru dam (figure 1). In June 2003, when the reservoir level was reduced to $209.2 \mathrm{~m}$ amsl, the springs disappeared. These springs again reappeared in October 2003, just after the monsoon, when the reservoir level was raised to $209.9 \mathrm{~m}$ amsl. The spring discharge rates were comparatively less, but the concern was that what would happen if the height of dam is increased, as it was proposed to increase the height of the dam in the next phase.

In the present study, an attempt has been made to identify the source and origin of springs observed in the hillock on the left flank of Gollaleru earthen dam, Nandyal, Andhra Pradesh, India using hydrometric, hydrochemical and environmental isotopes $\left(\delta^{18} \mathrm{O}, \delta^{2} \mathrm{H}\right.$ and $\left.{ }^{3} \mathrm{H}\right)$ techniques.

\section{Physiography, geology and hydrogeology of the study area}

Physiographically, the study area is having three main features: hills, gently undulating plains and valleys. Narji limestone occurs in a planar region and is surrounded by smooth topped hills of Gandikota quartzite and in some place, by mesas of Owk shale and Paniam quartzite. The major caves have been observed in well karstified massive limestone. Numerous seasonal karst springs is also seen in the foot of quartzite hills. These springs result from the rise in piezometric levels above the surface. Numerous small streams traverse the plain and forms narrow linear valleys. The drainage pattern of the area is dendritic.

The area falls in Cuddapah basin of Proterozoic age. Cuddapah basin, a crescent shaped sedimentary basin, located in the eastern part of Dharwar Craton in southern India and extending over approximately 44,500 $\mathrm{km}^{2}$ area (Crawford and Compston 1973; Kasipathi et al. 2008). It convexes towards west, having a length of about 400 $\mathrm{km}$ from north to south and maximum width of $145 \mathrm{~km}$ in the centre of the basin. It is divided into two groups: the older Cuddapah super group 


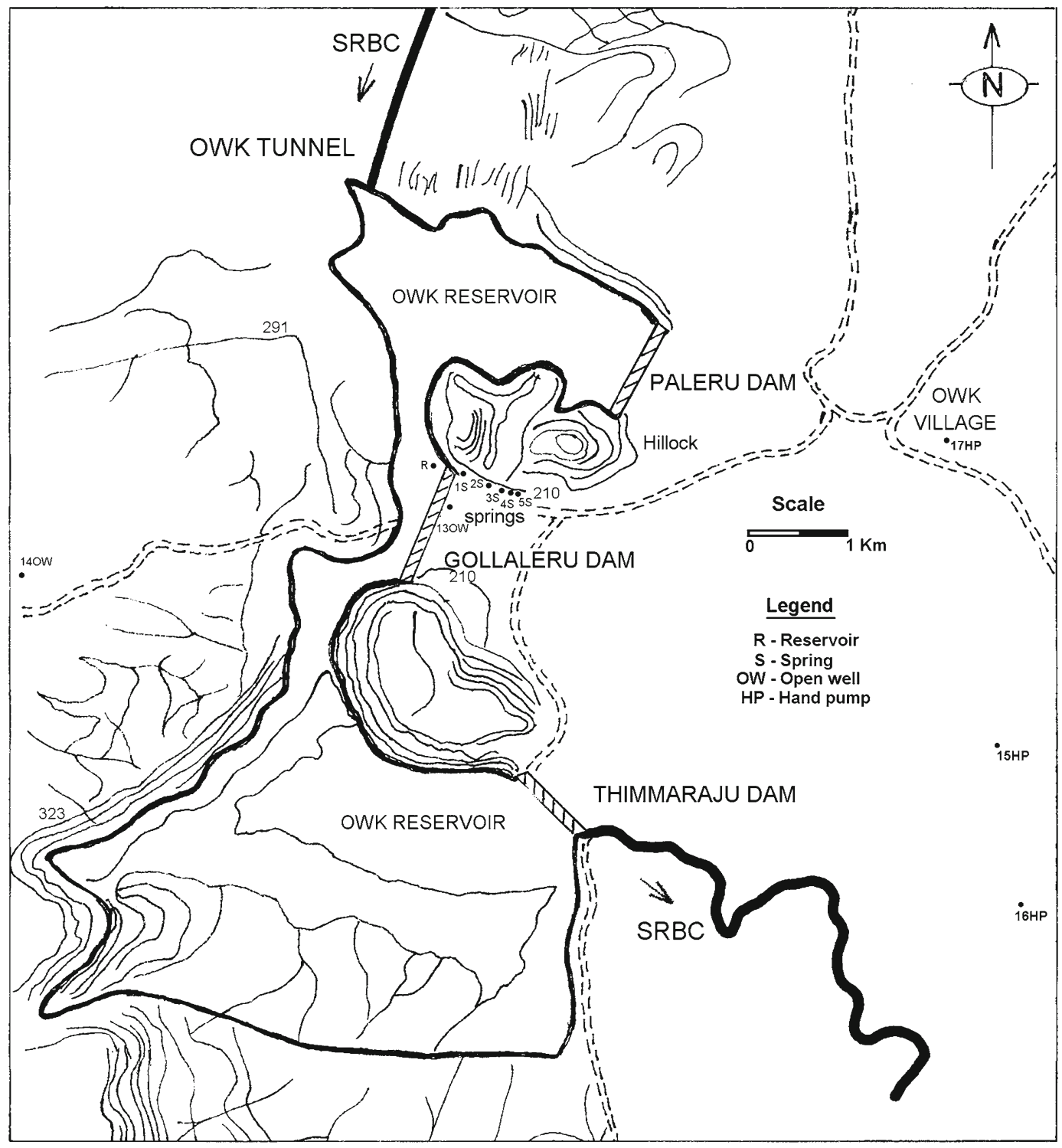

Figure 1. Location map of Gollaleru dam across the Owk reservoir, showing the local catchment, the sampling points and the location of springs.

and the younger Kurnool group which is separated by an unconformity and lie over a basement comprise of peninsular gneiss complex of Archean age (Meijerink et al. 1984). The stratigraphy of the western part of Cuddapah basin is given in table 1. The Cuddapah super group consists of mainly arenaceous and argillaceous sequences with minor amount of calcareous sediments, while the Kurnool group has more carbonate-rich geology. The lower Cuddapah group characterizes a cyclic recurrence of quartzite-shale sequence while the upper Kurnool group shows two quartzitelimestone-shale sequences (Raman et al. 1997). The older sequences are also manifested by contemporaneous igneous activity such as sills, flows and other intrusive rocks (Anand et al. 2003). The
Owk reservoir falls in Kurnool group. The Banganapalle formation composed of quartzite with conglomerate of boulder and pebbles form the basal part of the Kurnool group and unconformably lie over Cuddapah super group. The Banganapalle formation is overlain by Narji Formation. The Narji formation is made up of massive and flaggy limestone. Thin lenticular lenses of gritty ferruginous sandstone, inter-bedded shale, quartzite and intraformational conglomerates are also observed in basal part of the formation at several places. The Narji formation is overlain by the buff coloured shale of the Owk formation. The Owk formation consists of plane laminated yellow-ochre to white shale. This formation is conformably overlain by Paniam formation which is composed of quartzite. 
These formations are seen as remnants in the form of small hillocks (mesas) in the study area. The Paniam quartzite is overlain by the Koilkuntla formation made up of light to dark grey coloured, massive and flaggy limestone. The flaggy beds differ from Narji limestone by possessing imperfect, wavy planes of bedding. The lower part of the formation shows intercalation of shale, while the middle part is more calcareous, well bedded and tough. At the top, limestone colour changes to purple and is overlain by Nandyal formation. The Nandyal formation is composed of shale having earthy calcareous intercalation with $50-100 \mathrm{~m}$ thickness (Dar et al. 2011).

In crystalline rocks of the basement complex, groundwater occurs under unconfined to semiconfined condition in interconnected joints, fracture and voids. In shallow weathered zone groundwater occur under unconfined condition whereas in deep joints, fracture and fissures, it occurs under semi-confined conditions. The depth of irrigation wells vary from 4 to $26 \mathrm{~m}$ below ground level (bgl) in this formation (CGWB 2013). Groundwater occurs under unconfined and semi-confined conditions along the bedding planes, joints and in weathered and sheared zone in Panyam formation of Kurnool group. The depth of dug well varies from $7-13 \mathrm{~m} \mathrm{bgl}$ in this formation. Ground water occurs under unconfined conditions in the top weathered zones and karstified horizons in Koilkuntla limestone and in upper Nandyal formation. In Narji limestone and Banganapalle quartzite, groundwater occurs along bedding planes, joints and fissure. The depth to water level varies from 2.2 to $12.67 \mathrm{~m} \mathrm{bgl}$ during pre-monsoon whereas $0.47-22 \mathrm{~m} \mathrm{bgl}$ in post-monsoon period (CGWB 2013).

\section{Water sampling and analysis}

A set of 18 water samples were collected during December 2003 from the observed springs, the Owk reservoir and from the shallow as well as deep aquifers for the analyses of environmental isotopes such as deuterium $\left({ }^{2} \mathrm{H}\right.$ or $\left.\mathrm{D}\right)$, oxygen$18\left({ }^{18} \mathrm{O}\right)$ (figure 1$)$. The samples were collected in $60 \mathrm{ml}$ airtight high density polyethylene bottles. Water samples from various depths of the reservoir were collected with the help of a depth sampler. Groundwater samples were collected from existing open wells as well as from hand pumps located upstream and downstream of the reservoir. 
Physical parameters such as temperature, electrical conductivity (EC) and $\mathrm{pH}$ were measured in-situ using portable conductivity (EUTECH Cyberscan CON 11 Make) and pH (EUTECH Cyberscan pH 11 Make) meters, respectively. Representative sample from the reservoir and springs (1S and $5 \mathrm{~S}$ ) were collected for hydrochemical analyses. The collected water samples were filtered using $0.45 \mu \mathrm{m}$ pore size membrane filters and stored in polythene bottles for anion analysis. A duplicate set was collected and acidified to $\mathrm{pH}<2$ by adding ultrapure concentrated $\mathrm{HNO}_{3}$ for cation measurements. Alkalinity was measured in-situ by titrating $10 \mathrm{ml}$ of water sample with $0.02 \mathrm{~N} \mathrm{H}_{2} \mathrm{SO}_{4}$. Methyl orange indicator was used to mark the end point of the reaction. Alkalinity expressed in milligram $\mathrm{CaCO}_{3} / 1$ was multiplied by a factor of 1.22 for conversion to milligram $\mathrm{HCO}_{3}^{-} / 1$. Two more water samples, one from the reservoir and another from the first spring (1S) were collected during February 2004 for stable isotopes $\left({ }^{2} \mathrm{H}\right.$ and $\left.{ }^{18} \mathrm{O}\right)$ and environmental tritium $\left({ }^{3} \mathrm{H}\right)$ analyses.

Major ion chemistry (anions and cations) was measured in the laboratory using Ion Chromatograph (Dionex-500). For cationic analysis, $25 \mu \mathrm{l}$ of the filtered and acidified sample was introduced into a cation exchange column (CS 12A), where the ions were separated based on their charge to size ratio and were quantified using conductivity detector (ED 40). For anionic determination, $25 \mu \mathrm{l}$ of the filtered and non-acidified sample was introduced into an anion exchange column (AS 11) and measured.

For stable isotope $\left({ }^{2} \mathrm{H}\right.$ and $\left.{ }^{18} \mathrm{O}\right)$ analyses, water samples were measured in the laboratory using isotope ratio mass spectrometer (Geo-2020, PDZ Europa) using the gas equilibration method. For $\delta^{2} \mathrm{H}$ analysis, $1 \mathrm{ml}$ of the water sample was equilibrated with $\mathrm{H}_{2}$ along with $\mathrm{Pt}$ catalyst at $50^{\circ} \mathrm{C}$ for 1 $\mathrm{hr}$ and for $\delta^{18} \mathrm{O}$ analysis, $1 \mathrm{ml}$ of the water sample was equilibrated with $\mathrm{CO}_{2}$ gas at $50^{\circ} \mathrm{C}$ for $8 \mathrm{hr}$ and the equilibrated gases were introduced into the mass spectrometer. The results are reported in $\delta$-notation, as deviation relative to a standard, V-SMOW (Vienna - Standard Mean Ocean Water) and in units of parts per thousand (denoted as \%o). The $\delta$ values are calculated using (Coplen 1996):

$$
\delta(\%)=\left(\frac{R_{x}}{R_{s}}-1\right) \times 1000
$$

where $R$ denotes the ratio of heavy to light isotope (e.g., ${ }^{2} \mathrm{H} /{ }^{1} \mathrm{H}$ or ${ }^{18} \mathrm{O} /{ }^{16} \mathrm{O}$ ) and $R_{x}$ and $R_{s}$ are these ratios in the sample and standard respectively. The precision of measurement for $\delta^{2} \mathrm{H}$ is $\pm 1 \%$ and for $\delta^{18} \mathrm{O}$ is $\pm 0.1 \%(2 \sigma)$.

The tritium content was measured using liquid scintillation counter (Quantulus 1220) following the standard procedures, after electrolytic enrichment (Nair 1983). It is expressed in terms of Tritium Units (TU). 1 TU of sample has ${ }^{3} \mathrm{H} /{ }^{1} \mathrm{H}$ ratio equals to $10^{-18}$, which corresponds to $0.12 \mathrm{~Bq} / \mathrm{l}$ of water. The minimum detection limit is $0.5 \mathrm{TU}(3 \sigma)$.

\section{Results and discussion}

Field parameters along with the results of isotope and hydrochemical analyses are given in tables 2 and 3. It was found that the flow rate of the first spring (1S) was more than the sum of the discharges of other four springs. The average temperatures of springs and shallow groundwater were $28.6 \pm 1.1^{\circ} \mathrm{C}$ and $27.9 \pm 2.8^{\circ} \mathrm{C}$ respectively, while those of Owk reservoir was $25.5 \pm 0.2^{\circ} \mathrm{C}$. The electrical conductivity (EC) of the springs varied from 1595 to $2220 \mu \mathrm{S} / \mathrm{cm}$ indicating that the spring water was brackish while the shallow groundwater was fresh to saline (EC varied from 148 to $7650 \mu \mathrm{S} / \mathrm{cm}$ ). The electrical conductivity of Owk reservoir falls in a narrow range of 222 $225 \mu \mathrm{S} / \mathrm{cm}$ indicating fresh water. The springs and shallow groundwater are slightly acidic to neutral ( $\mathrm{pH}$ varied from 6.25 to 7.52$)$ while the Owk reservoir is slightly alkaline in nature $(\mathrm{pH}$ varied from 7.30 to 8.13 ). The variations in the above parameters indicate that the springs have almost similar physical characteristics as that of the groundwater.

Variation of physico-chemical parameters such as temperature, electrical conductivity, $\mathrm{pH}$ and stable isotopes $\left(\delta^{18} \mathrm{O}\right.$ and $\left.\delta^{2} \mathrm{H}\right)$ in springs located at 0,9 , 26, 44 and $54 \mathrm{~m}$ from the toe of the dam are shown in figure 2. It is seen that the temperature and electrical conductivity in the springs decrease with distance from the toe of the dam while $\mathrm{pH}$ increases with the distance. The $\delta^{18} \mathrm{O}$ and $\delta^{2} \mathrm{H}$ values remain more or less same in the springs.

Since the study area is in a limestone terrain where conduit flow can occur through the subsurface, it is quite possible that the different springs have different flow paths and residence times. Based on the physico-chemical parameters, it is inferred that the spring close to the dam (IS) has slightly higher temperature and electrical conductivity; but lower $\mathrm{pH}$ (characteristics 


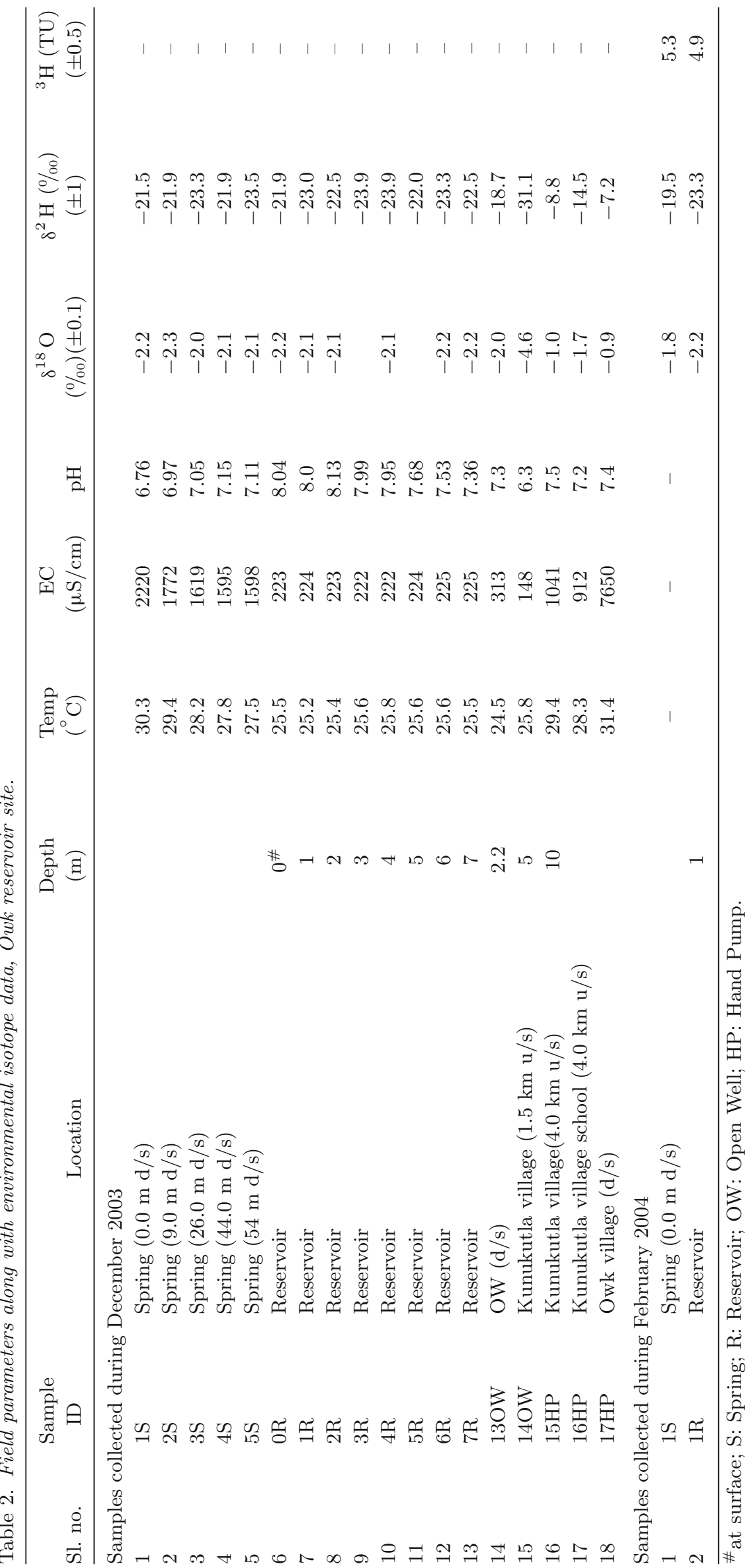


Table 3. Chemical analysis data of reservoir (average of three samples) and spring samples (1S and 5S), Owk reservoir site.

\begin{tabular}{lcll}
\hline Parameter & $\begin{array}{c}\text { Reservoir } \\
\text { water }(\mathrm{mg} / \mathrm{l})\end{array}$ & $\begin{array}{c}\text { Spring (1S) } \\
(\mathrm{mg} / \mathrm{l})\end{array}$ & $\begin{array}{c}\text { Spring (5S) } \\
(\mathrm{mg} / \mathrm{l})\end{array}$ \\
\hline $\mathrm{Na}^{+}$ & 10.8 & 280.5 & 211.8 \\
$\mathrm{~K}^{+}$ & 2.5 & 5.6 & 7.0 \\
$\mathrm{Ca}^{2+}$ & 39 & 270.5 & 174.1 \\
$\mathrm{Mg}^{2+}$ & 5 & 56.6 & 46.9 \\
$\mathrm{Li}^{+}$ & 0 & 0.1 & 0.4 \\
$\mathrm{Sr}^{2+}$ & 0 & 1 & - \\
$\mathrm{NH}_{4}^{+}$ & $\mathrm{np}$ & $\mathrm{np}$ & 7.2 \\
$\mathrm{Cl}^{-}$ & 8.1 & 170 & 107.5 \\
$\mathrm{SO}_{4}^{2-}$ & 0.67 & 643 & 378.3 \\
$\mathrm{NO}_{3}^{-}$ & $\mathrm{np}$ & $\mathrm{np}$ & $\mathrm{np}$ \\
$\mathrm{HCO}_{3}^{-}$ & 195 & 427 & 275 \\
\hline
\end{tabular}

Note. np: not present.
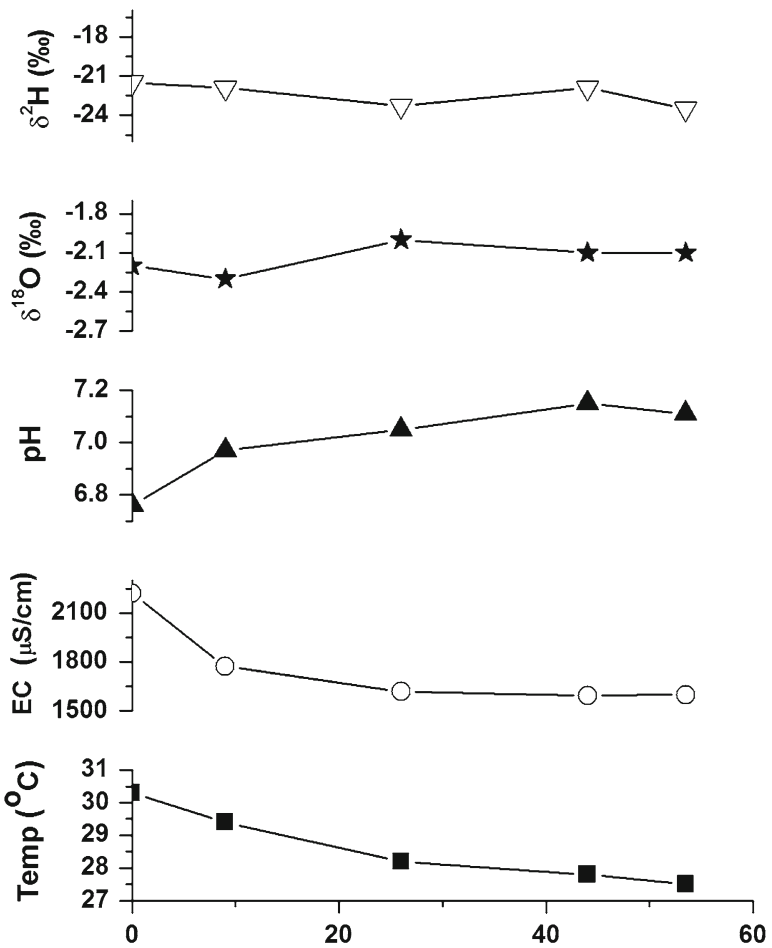

Distance to the springs from the toe of the dam (m)

Figure 2. Variation of field parameters and stable isotopes $\left(\delta^{18} \mathrm{O}\right.$ and $\left.\delta^{2} \mathrm{H}\right)$ in springs located at various distances from the toe of the dam.

similar to that of groundwater) compared to the springs away from the dam (5S), which is having comparatively lower temperature and electrical conductivity; but higher $\mathrm{pH}$ (characteristics similar to that of reservoir water). The relatively higher temperature and electrical conductivity and lower $\mathrm{pH}$ value of the first spring (1S) indicate that the

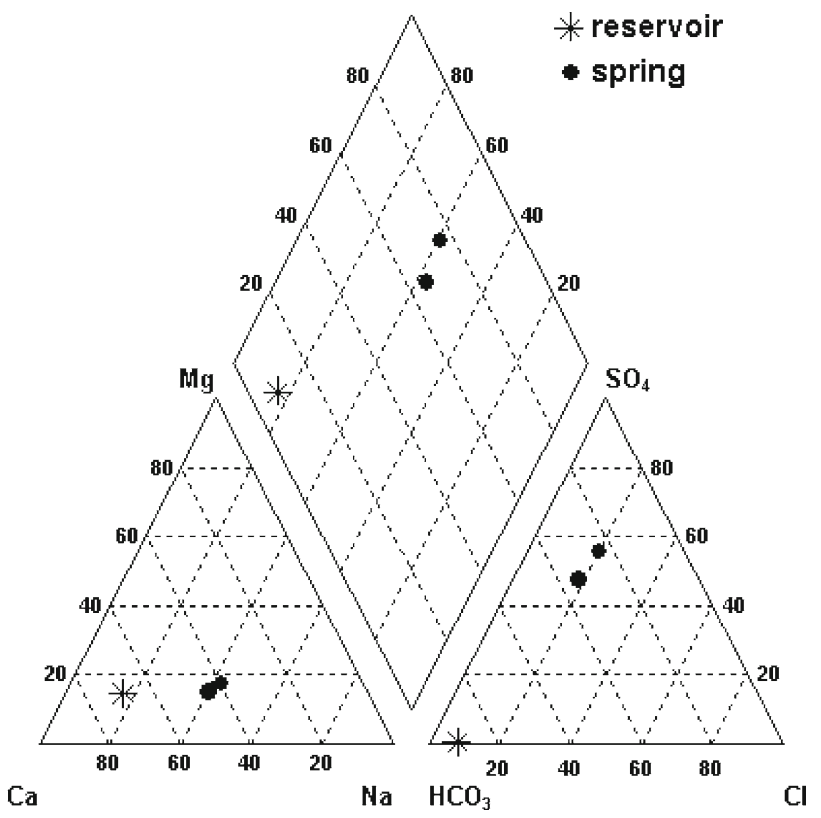

Figure 3. Piper's trilinear diagram.

contribution of groundwater (average temperature of $\mathrm{OW}=25.2^{\circ} \mathrm{C}, \mathrm{HP}=29.7^{\circ} \mathrm{C}$; average $\mathrm{EC}$ of $\mathrm{OW}=230 \mu \mathrm{S} / \mathrm{cm}, \mathrm{HP}=3200 \mu \mathrm{S} / \mathrm{cm}$; average $\mathrm{pH}$ of $\mathrm{OW}=6.8, \mathrm{HP}=7.4)$ to this spring was significant, while other springs were getting varying amounts of reservoir contribution. However, the difference in physico-chemical parameters between the springs $1 \mathrm{~S}$ and $5 \mathrm{~S}$ is not very high. Hence, the spring away from the dam (5S) may be having lesser transit time, shallow circulation with more reservoir component. Whereas, the spring close to the dam (1S) may be having longer transit time, deeper circulation and more groundwater component.

The hydrochemical species of the water samples collected from the springs (1S and $5 \mathrm{~S}$ ) and reservoir water are shown in the Piper's trilinear plot (Piper 1994) (figure 3). Piper's diagram indicates that the reservoir water is $\mathrm{Ca}-\mathrm{HCO}_{3}$ type whereas spring water is $\mathrm{Na}-\mathrm{Ca}-\mathrm{SO}_{4}-\mathrm{HCO}_{3}$ type. Hence, the spring water is chemically different from the reservoir water. It substantiates the fact that the springs may be getting some contribution from the local groundwater.

The stable ${ }^{18} \mathrm{O}$ and ${ }^{2} \mathrm{H}$ isotopes of water are generally considered to behave conservatively in the absence of significant evaporation and mixing with other water of different isotopic signatures. However, the physical processes such as evaporation and condensation of water causes stable isotopic variations during the liquid-vapor phase 
change, and get labeled naturally with distinct isotopic signatures depending on their geographical locations. By tracing the naturally labeled isotopic signatures, it is possible to obtain several information related to surface water-groundwater interactions and associated hydrological processes. Environmental tritium $\left({ }^{3} \mathrm{H}\right)$, sourced from the fallout of thermo-nuclear weapons testing, carried out in the atmosphere during 1950-1963, could be effectively used to identify the recent recharge (estimate residence time) from precipitation or surface water bodies to groundwater.

The $\delta^{18} \mathrm{O}$ and $\delta^{2} \mathrm{H}$ in the springs fall in a narrow range and varied from -2.3 to $-1.8 \%$ and -23.5 to $-21.5 \%$, respectively, which is isotopically similar to that of reservoir water $\left(\delta^{18} \mathrm{O}=-2.2\right.$ to $-2.1 \%$ and $\delta^{2} \mathrm{H}=-23.9$ to $-21.9 \%$ oo $)$. While, the $\delta^{18} \mathrm{O}$ values of shallow groundwater varied from -4.6 to $-0.9 \%$ and $\delta^{2} \mathrm{H}$ values varied from -31.1 to $-7.2 \%$. They are isotopically different, when compared to reservoir and springs. Hence, the recharge from the reservoir to the local groundwater seems to be negligible. The $\delta^{2} \mathrm{H} v s . \delta^{18} \mathrm{O}$ plot of spring, reservoir and groundwater samples are shown in figure 4 along with the Global Meteoric Water Line (GMWL). The GMWL is constructed with the $\delta^{18} \mathrm{O}$ and $\delta^{2} \mathrm{H}$ of precipitation occurring all over the world. The equation for this line is given by Craig (1961):

$$
\delta^{2} \mathrm{H}=8 \delta^{18} \mathrm{O}+10 .
$$

For the site-specific interpretation of stable isotope data, Local Meteoric Water Line (LMWL) need to be constructed based on the isotopic values of local precipitation. In the absence of stable isotope data of precipitation in the study area, isotope data of precipitation for the period September 1997-November 2000, available at International Atomic Energy Agency's (IAEA) Global Network of Isotopes in Precipitation (GNIP) station namely Hyderabad (which is $180 \mathrm{~km}$ from Nandyal) was used to construct the LMWL as shown in figure 4 (IAEA-WMO 2016).

Although the study area receives both southwest monsoon (June-September) and northeast monsoon (October-November), it predominantly receives southwest monsoon which is having relatively enriched stable isotopic composition $\left(\delta^{18} \mathrm{O}=-4.7\right.$ to $-0.6 \% ; \delta^{2} \mathrm{H}=-28$ to +0.9$)$. The northeast monsoon is characterised by relatively depleted isotopic composition with $\delta^{18} \mathrm{O}$ values varied from -8 to $-10 \%$ and $\delta^{2} \mathrm{H}$ varied from -53 to $-70 \%$ (IAEA-WMO 2016). However, since the contribution from northeast monsoon is very low, the weighted mean $\delta^{18} \mathrm{O}$ and $\delta^{2} \mathrm{H}$ values of monthly precipitation are found to be $-4.5 \%$ and $-27.5 \%$, respectively.

The equation for the LMWL is given by:

$$
\begin{aligned}
\delta^{2} \mathrm{H} & =(7.3 \pm 0.3) \delta^{18} \mathrm{O}+(5 \pm 1) \\
(n & \left.=25 ; r^{2}=0.97\right) .
\end{aligned}
$$

The lower slope and y-intercept of LMWL compared to GMWL indicate that the falling raindrops had undergone evaporation. The shallow groundwater (hand pump and open well), which is essentially recharged by precipitation, falls off the LMWL indicating slight evaporation. The Best-fitline (BFL) for these samples is given by:

$$
\begin{aligned}
\delta^{2} \mathrm{H} & =(6.3 \pm 0.7) \delta^{18} \mathrm{O}-(3 \pm 2) \\
(n & \left.=5 ; r^{2}=0.95\right) .
\end{aligned}
$$

The reservoir water falls on the right hand side of the LMWL in the $\delta^{18} \mathrm{O}$ vs. $\delta^{2} \mathrm{H}$ plot indicating that it was subjected to significant evaporation. The BFL or the evaporation line (EL) constructed from the isotopic values of reservoir water and the weighted mean monthly precipitation is given by:

$$
\begin{aligned}
\delta^{2} \mathrm{H} & =(1.9 \pm 0.3) \delta^{18} \mathrm{O}-(19 \pm 1) \\
(n & \left.=7 ; r^{2}=0.83\right) .
\end{aligned}
$$

For the construction of EL, the isotopic value of weighted mean monthly precipitation is also included along with the reservoir values because of the fact that the reservoir water is essentially derived from the precipitation and no trend is observed if reservoir values alone are plotted.

The EL has a lower slope and negative $\mathrm{y}$ intercept compared to LMWL. It is obvious that closed surface water bodies such as lakes and reservoirs have enriched stable isotopic composition due to kinetic effects (Eriksson 1983). This effect is more prominent in $\delta^{18} \mathrm{O}$ than in $\delta^{2} \mathrm{H}$. The spring samples fall predominantly near the reservoir water and on a mixing line between the reservoir water and the shallow groundwater in the $\delta^{18} \mathrm{O}-\delta^{2} \mathrm{H}$ plot. This indicates that the observed springs were essentially originated from the reservoir. The first spring (1S) sample collected in February 2004 falls in the mixing line, but slightly away from the reservoir samples indicating some contribution from the local groundwater. 


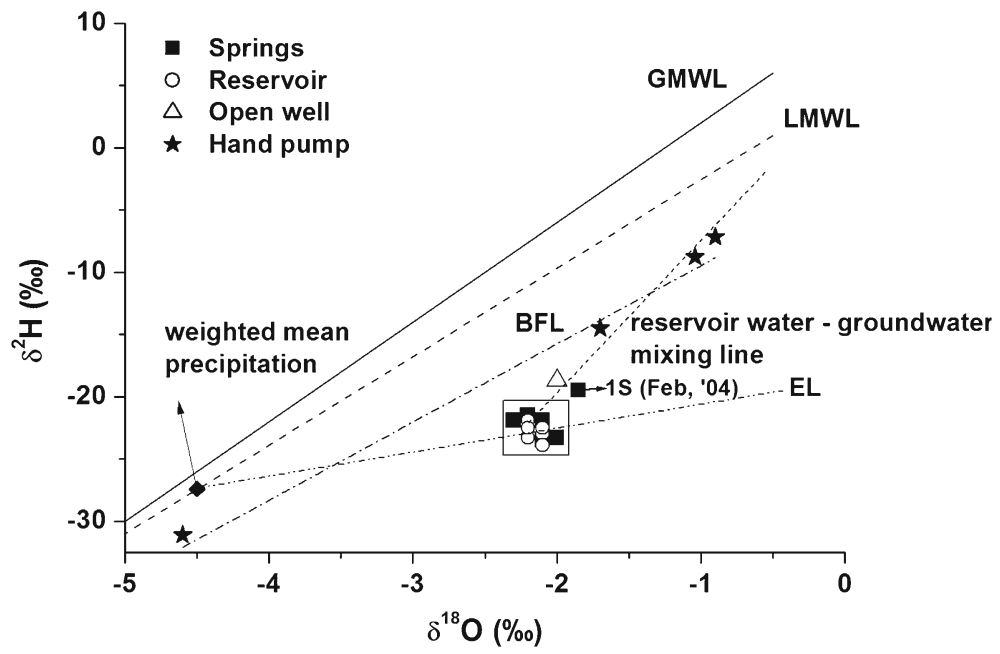

Figure 4. $\delta^{18} \mathrm{O}-\delta^{2} \mathrm{H}$ plot of samples collected from Owk reservoir site.

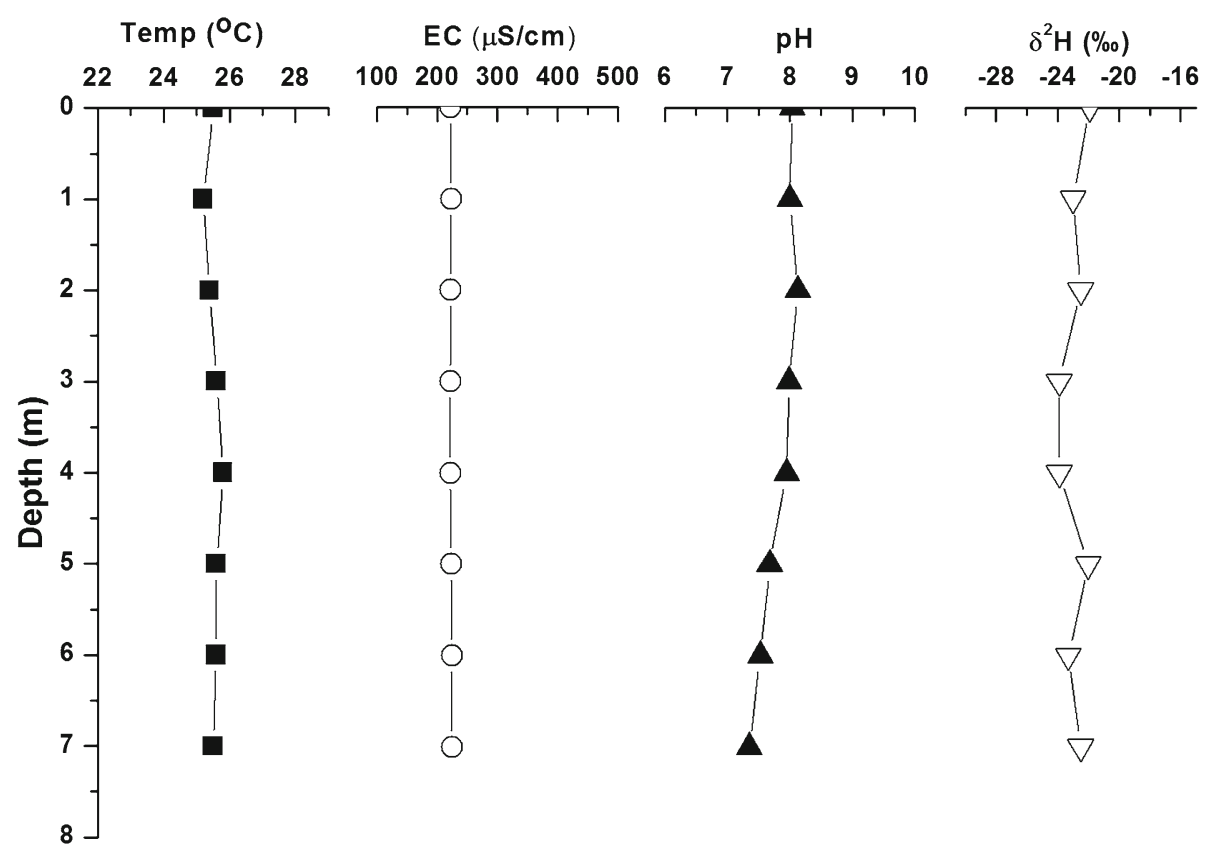

Figure 5. Vertical profiles of temperature, electrical conductivity, $\mathrm{pH}$, and $\delta^{2} \mathrm{H}$ in the Owk reservoir during winter.

Although isotope results show that the springs were originated from the reservoir, the higher physical and chemical constituents present in springs compared to the reservoir water, points to the fact that the reservoir water is not immediately coming out as springs. The reservoir water is getting sufficient time in the subsurface to interact with the geological formation and acquire minerals. Hence, it is quite possible that the reservoir water during its flow through the subsurface can acquire minerals and change its original chemical composition. Hence, the use of only hydrochemical indicators can be sometimes misleading. Whereas, the natural isotopes of water, being a conservative tracer of water molecule, could be useful to differentiate the various possible sources of springs.

Since the water samples were collected (in December 2003) when the reservoir levels were relatively lower, the hydraulic gradient might be low and consequently the spring discharges were low. Hence, it is possible that the spring discharges during this period were seepage water (as discussed in the subsequent sections) which is a mixture of reservoir water with a little contribution from the shallow groundwater. 
Tritium content of the reservoir and spring samples show similar values, about $5 \mathrm{TU}$. The high tritium content of spring sample indicates that it is fed by modern water.

The thermal (temperature induced) stratification observed in lakes and reservoirs during summer provides valuable information on the depth at which the emerging water infiltrate from the reservoir, if they are hydraulically connected. Figure 5 shows the vertical profiles of electric conductivity, $\mathrm{pH}$, temperature and $\delta^{2} \mathrm{H}$ measured in the Owk reservoir during December 2003. It is clearly seen that all the above parameters do not vary with depth. Since the sampling was carried out in winter, like many other lakes and reservoirs, Owk reservoir is also in well mixed condition. Since vertical stratification is not seen in the Owk reservoir, it is difficult to locate the depth at which the water is seeping from the reservoir.

The relationship between the water level at the reservoir and the flow rate of the springs can provide valuable information on the elevation interval inside the reservoir where the infiltration of the emerging water at the springs is taking place. The variation of Owk reservoir level and the rate of spring discharge from February 2003-January 2004 are shown along with precipitation data collected at the Owk village (figure 6). From the figure, it is seen that the springs follow the same pattern as that of the change in reservoir level, i.e., when the reservoir level increases the spring discharge increases and when the reservoir level decreases the spring discharge also decreases. In March 2003, when the reservoir level was raised to $212.4 \mathrm{~m}$ amsl by the release of Krishna river water from the Srisailam dam, the discharge of spring close to the dam (1S) increased to $1.0 \mathrm{l} / \mathrm{s}$ while the total discharge of rest of the springs (2S-5S) increased to $1.17 \mathrm{l} / \mathrm{s}$. In the beginning of June 2003, when the reservoir level was dropped to $209.2 \mathrm{~m}$ amsl, the springs disappeared. Since the rainfall in Nandyal during 2003 was scanty, the runoff from the local catchment could only slightly increase the reservoir level. When the reservoir level rose to $209 \mathrm{~m}$ amsl, the springs reappeared. The maximum reservoir level attained after the monsoon was $210.7 \mathrm{~m}$ amsl in October and the total spring discharge increased to $0.8 \mathrm{l} / \mathrm{s}$. Therefore, from the hydrometric observations, it is inferred that the springs might be originated from the reservoir level of $209 \mathrm{~m}$ amsl, i.e., the level at which the appearance and disappearance of the springs.
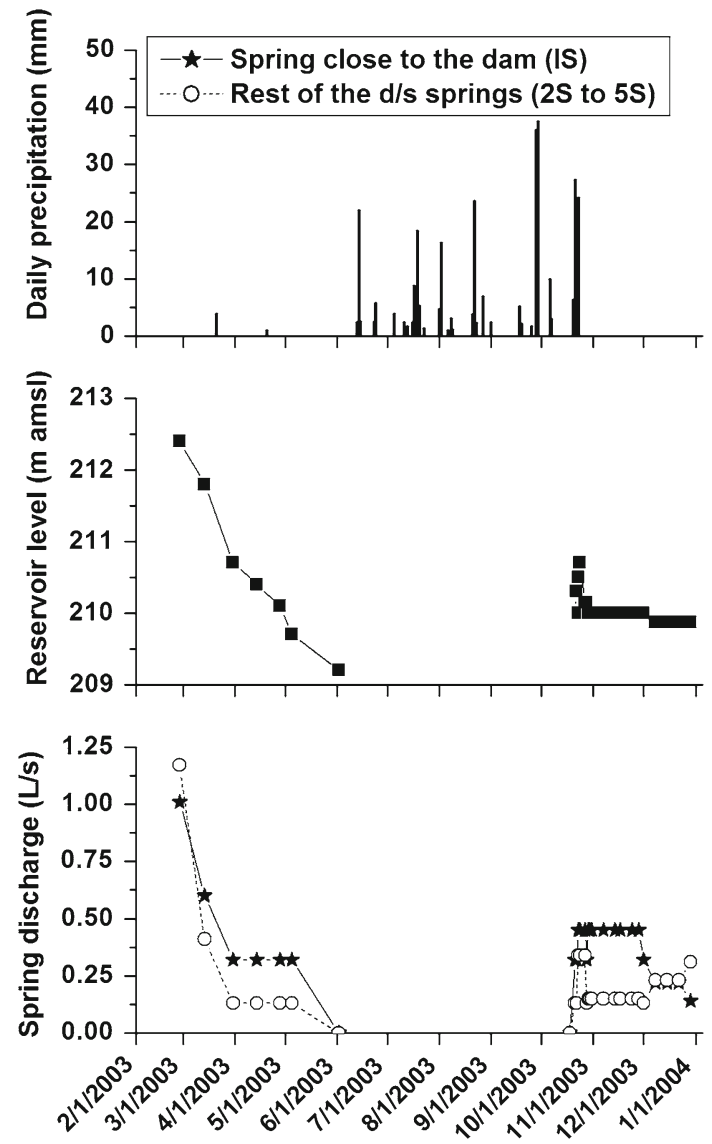

Figure 6. Temporal variation of reservoir level, spring discharge rate and amount of precipitation from February 2003 to January 2004.

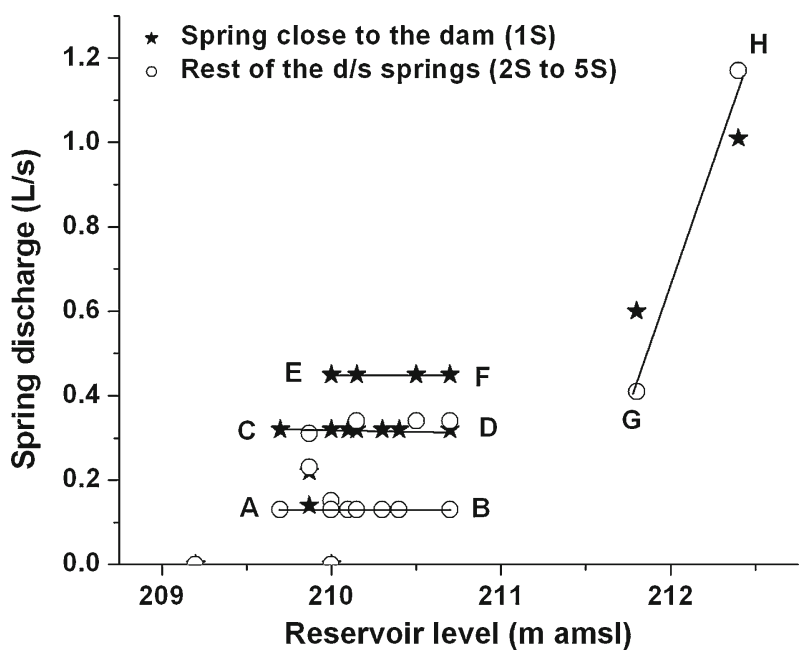

Figure 7. Plot of reservoir level vs. rate of spring discharge.

The correlation between the reservoir level and rate of spring discharge generally reveal the nature of seepage or leakage. Figure 7 shows the correlation between the reservoir level and spring discharge at Owk reservoir site. It is seen that 
when the reservoir level gradually increased from 209.6 to $210.7 \mathrm{~m}$ amsl, or decreased from 210.7 to $209.6 \mathrm{~m}$ amsl, there was no appreciable increase or decrease in spring discharge rates. The spring discharge rate varied only from 0.1 to $0.5 \mathrm{l} / \mathrm{s}$ and is shown in straight lines $(\mathrm{AB}, \mathrm{CD}$ and $\mathrm{EF})$ parallel to the $\mathrm{x}$-axis in figure 7 , during the rising and falling of water levels in the reservoir.

It indicates that the spring discharge in this range is mainly derived from diffuse sources, i.e., seepage, which could be a mixture of reservoir water with a little contribution from the groundwater. On the other hand, when the reservoir level increased from 211.8 to $212.4 \mathrm{~m}$ amsl, the spring discharge rate increased linearly from 0.4 to $1.2 \mathrm{l} / \mathrm{s}$ as shown by the line GH (figure 7 ). It indicates that the relatively higher spring discharge rate in this range is derived from concentrated sources, i.e., leakage from the reservoir.

\section{Conclusion}

From this study, it is concluded that the source of springs observed on the foot of the hillock abutting the left flank of the Gollaleru dam is from the Owk reservoir. However, some contributions from the local groundwater cannot be ruled out. Transit time of reservoir water in the subsurface through various flow paths (solution channels) is identified as a parameter which determines the chemical characteristics of the spring water. Based on hydrometric observations, it is inferred that the springs might be originated from the reservoir level of $209 \mathrm{~m}$ amsl. It is found that the lower spring discharges were derived from diffuse sources (seepage) which could be a mixture of reservoir water and groundwater, while, the relatively higher spring discharges were resulted from concentrated sources (leakage) from the reservoir.

The study portraits the usefulness of isotope techniques in understanding the dam seepage/ leakage related problems.

\section{Acknowledgements}

The authors wish to thank the officials of Irrigation Department, Nandyal, for the help during the field visit. Thanks are also due to Dr U K Sinha, Head, Isotope Hydrology Section, Isotope \& Radiation Application Division (IRAD), BARC and Mr K S S Sarma, Head, IRAD, BARC for their encouragement and support. They sincerely thank the anonymous reviewers for their insightful comments and suggestions for improving the manuscript.

\section{References}

Anand M, Gibson S A, Subbarao K V, Kelley S P and Dickin A P 2003 Early Proterozoic melt generation processes beneath the intracratonic Cuddapah Basin, southern India; J. Petrol. 44 2139-2171.

Aral M and Maslia M 1983 Unsteady seepage analysis of Wallace Dam; J. Hydraul. Eng. 109 809-826.

Bedmar A P and Araguas L A 2002 Detection and prevention of leaks from dams; Balkema Publishers, Tokyo.

Cho I K and Yeom J Y 2007 Cross line resistivity tomography for the delineation of anomalous seepage pathways in an embankment dam; Geophysics 72 31-38.

CGWB 2013 Ground water brochure, Kurnool district, Andhra Pradesh, Central Ground Water Board, Southern region, Hyderabad.

Clark I and Fritz P 1997 Environmental Isotopes in Hydrogeology; Lewis Publ., New York, 327p.

Coplen T B 1996 New Guidelines for reporting stable hydrogen, carbon and oxygen isotope-ratio data; Geochem. Cosmochem. Acta 603359.

Craig H 1961 Isotopic variation in meteoric waters; Science 133 1702-1703.

Crawford A R and Compston W 1973 The age of the Cuddapah and Kurnool systems, southern India; J. Geol. Soc. Australia 19(4) 453-464.

Dar F A, Perrin J, Riotte J, Gebauer H D, Narayana A C and Ahmed S 2011 Karstification in the Cuddapah sedimentary basin, southern India: Implications for groundwater resources; Acta Carsologica 40(3) 457-472.

Eriksson E 1983 Stable isotopes and tritium in precipitation; Chapter 2, Guide Book on Nuclear Techniques in Hydrology, Technical Report IAEA Vienna 91 19-33.

Fan Z, Wang J and Mao H 2014 Studying leakage from left abutment of Xiaolangdi hydropower station using tracing method; J. Chem. Pharma. Res. 6 2062-2068.

Gurocak Z and Alemdag S 2011 Assessment of permeability and injection depth of the Atasu dam site (Turkey) based on experimental and numerical analyses; Bull. Eng. Geol. Environ. 71 221-229.

Hien P D and Ki-Ioi L V 1996 Application of isotope tracer techniques for assessing the seepage of the hydropower dam at Tri An, South Vietnam; J. Radioanal. Nucl. Chem. 206 295-303.

IAEA-WMO 2016 Global Network of Isotopes in Precipitation; The GNIP database, http://www.naweb.iaea.org/ napc/ih/IHS_resources_gnip.html.

Iya V K, Krishnamurthy K, Aggarwal K S and Rajagopalan $\mathrm{R} 1967$ A radiotracer study on flowpath of seepage in the coffer dams at Srisailam; Appl. Radiat. Isot. 18 349-357.

Kasipathi C, Arjunudu K, Rao K S and Rao M S 2008 Cuddapah formations of Andhra Pradesh, India. A new report of prospects for rich banded iron ore formation; J. Pure Appl. Sci. 2(1) 227-233. 
Lee J Y, Choi Y K, Kim H S and Yun S T 2005 Hydrologic characteristics of a large rock fill dam: Implications for water leakage; Eng. Geol. 80 43-59.

Lee J Y, Kim H S, Choi Y K, Kim J W, Cheon J Y and Yi M J 2007 Sequential tracer tests for determining water seepage paths in a large rock fill dam, Nakdong River basin, Korea; Eng. Geol. 89 300-315.

Meijerink A M J, Rao D P and Rupke J 1984 Stratigraphic and structural development of the Precambrian Cuddapah Basin, SE India; Precamb. Res.26 57-104.

Nair A R 1983 Possibilities of liquid scintillation counting for tritium and radiocarbon measurements in natural water; Proc. Workshop on Isotope Hydrology, BARC Mumbai, pp. $41-56$.

Panthulu T V, Krishnaiah C and Shirke J M 2001 Detection of seepage paths in earth dams using self-potential and electrical resistivity methods; Eng. Geol. 59 281-295.

Peng T R and Wang C H 2008 Identification of sources and causes of leakage on a zoned earth dam in northern Taiwan: Hydrological and isotopic evidence; Appl. Geochem. $232438-2451$.
Piper A M A 1994 Graphical procedure in the geochemical interpretation of water analysis; EOS Trans. Am. Geophys. Union 25 914-928.

Ramam P K and Murthy V N 1997 Purana basins: Cuddapah, Pakhal, Bhima; Geology of Andhra Pradesh, Geological Society of India, Bangalore, pp. 119-136.

Saha D and Tripathy V 2012 Paleoproterozic sedimentation in the Cuddapah basin, south India and regional tectonics: A review; In: Paleoproterozoic of India (eds) Mazumder $\mathrm{R}$ and Saha D, Geol. Soc. London Spec. Publ. 365 5-28.

Saravana Kumar U, Sharma S and Navada S V 2008 Recent studies on surface water-groundwater relationships at hydro-projects in India using environmental isotopes; Hydrol. Process. 22 4543-4553.

Sjödahl P, Dahlin T, Johansson S and Loke M H 2008 Resistivity monitoring for leakage and internal erosion detection at Hällby embankment dam; J. Appl. Geophys. 65 155-164.

Unal B, Eren M and Yalcin M G 2007 Investigation of leakage at Ataturk dam and hydroelectric power plant by means of hydrometric measurements; Eng. Geol. 93 45-63. 